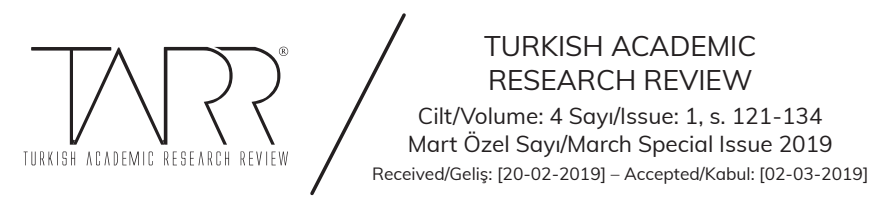

\title{
Bir Din Âlimi Olarak Hasan Hüsnü Erdem ve Enfâl Suresinin Altmışıncı Ayeti Hakkındaki Yorumu ${ }^{1}$
}

Yasin Pişgin ${ }^{2}$

\section{Özet}

Antalya, bir yandan Elmalılı Muhammed Hamdi Yazır, Ahmet Hamdi Akseki ve İbrahim Bedrettin Elmalı gibi son devrin büyük âlimlerinin, diğer yandan da Vâhib-i Ümmî, Sinân-1 Ümmî ve Eroğlu Nuri gibi Anadolu irfanını besleyen büyük ariflerin yetiştiği önemli bir kültür havzasıdır. Üç Diyanet İşleri Başkanı çıkarmış olması bile başlı başına bu şehrin tarih boyunca Anadolu'nun ilim ve irfan dünyasına sağladığı katkılar hakkında fikir vermeye yeterlidir. Altıncı Diyanet İşleri Başkanı Hasan Hüsnü Erdem de bu ilim ve irfan ikliminin yetiştirdiği seçkin şahsiyetlerden biridir. $\mathrm{O}$, milli ve manevi değerleri aynı potada eriten, kültürel köklerine bağlı ve geniş ufuklu bir dava adamıdır. Milli mücadelede aktif bir şekilde rol alan Erdem, vaaz ve hutbeleriyle milletin direniş azmini ve şuurunu bilemiştir. Biz bu çalışmamızda bir din âlimi olarak Hasan Hüsnü Erdem'i ve o'nun bir vaazında Enfâl Suresinin altmışıncı ayeti ile ilgili yaptığı yorumu incelemeye çalışacağız.

Anahtar Kelimeler: Hasan Hüsnü Erdem, Diyanet İşleri Başkanı, Din Âlimi, Enfâl Suresi.

\section{Hasan Hüsnü Erdem as a Religious Scholar and His Commentary on The Sixtieth Verse of The al-Anfal}

\begin{abstract}
Antalya is an important cultural basin where -on the one hand- the great scholars of the last century were trained there such as Elmalılı Muhammed Hamdi Yazır, Ahmet Hamdi Akseki and İbrahim Bedrettin Elmalı and -on the other hand- the great lore owners that feed lore of Anatolia such as Vâhib-i Ümmî, Sinân-i Ummî and Eroğlu Nûrî. Even if heading of this city Three Religious Affairs Presidents, it is enough to give an idea about the the contributions of this city to the world Anatolia's knowledge and lore in throughout history. Hasan Hüsnü Erdem, the President of the Sixth Religious Affairs, is one of the distinguished personalities

1 Bu makale 11-12 Kasım 2016 tarihinde Antalya'da düzenlenen "6. Diyanet İşleri Reisi Hasan Hüsnü Erdem Sempozyumu”nda sunduğumuz "Bir Din Âlimi Olarak Hasan Hüsnü Erdem” başlıklı bildiri metninin kaynak ve içerik bakımından genişletilmiş halidir.

2 Doç. Dr., Akdeniz Üniversitesi İlahiyat Fakültesi. e-posta: yasinpisgin@akdeniz.edu.tr
\end{abstract}


raised by this knowledge and lore climate. He is a man of ideal who are melting the national and spiritual values in the same pot, tied to his cultural roots and having a broad horizon. Erdem, who plays an active role in the national struggle, has sharpened the resistance and consciousness of the nation. In this work, we will try to examine Hasan Hüsnü Erdem as a religious scholar and his comment in his sermon related to the sixtieth verse of the Al-Anfâl.

Key words: Hasan Hüsnü Erdem, President of Religious Affairs, Religion Scholar, Sura Al-Anfal.

\section{Giriş}

Bir âlim tanıtılır veya değerlendirilirken yaşadığı dönemi, içinde yetiştiği toplumun kültürel yapısını, o'nun karakterini, eğitimini, hocalarını, toplum içerisindeki statüsünü, üstlendiği görevleri, eserlerini ve bunları te’lif amacını bilmek önem arz etmektedir. ${ }^{3}$ Bir âlimin ilmî karakterinin şekillenmesine katkı sağlayan bu parametreler 1şı̆̆ında, altıncı diyanet işleri başkanı Hasan Hüsnü Erdem bir makalenin imkânları ölçüsünde bir din âlimi olarak tanıtılmaya çalışılacaktır. Ayrıca Türkçe ezan ve Türkçe Kur'an'a bakışı özelinde ilmî şahsiyetiyle durduğu yer ve Enfâl Suresi'nin 60. ayetine ilişkin yorumu ele alınmaya çalışılacaktır.

\section{Bir Din Âlimi Olarak Hasan Hüsnü Erdem}

1889 yılında Akseki’nin Sadıklar köyünde doğdu. Babası Müderris Hacı Sadık Efendi; dedesi ise Şeyh Hasan Efendidir. Babası, Kadı Beydâvî tefsirinin ilk cildinin ilk sayfasına kendi el yazısıyla şöyle yazmıştır: "1336 senesi Zilkadetü'ş-Şerîf'in onuncu günü yevm-i isneny vakt-i duhada oğlum Hasan Hüsnü dünyaya tulû eyledi.” Doğum tarihinin not düşüldüğü bu eser, Erdem'in nasıl bir ilim ve irfan ortamında gözlerini açtığını ifade etmesi bakımından önemlidir. O, ilk olarak babasından Arapça ve mantık dersleri almıştır. Hatta vaaz konusunda ilk örnek aldığı şahsiyet de babasıdır. Daha on dört yaşındayken köy camisinde vaaz kürsüsüne çıkmış ve anlatım üslubuyla takdir kazanmıştır. ${ }^{4}$

İlim tahsili için bir müddet Konya'da bulunmuş, akabinde İstanbul'a gitmiş, Fetva Emini Muğla’lı Ali Rıza ve Fatih dersiamlarından Bayındırlı Mehmet Şükrü Efendilerden ilim tahsil etmiş ve icazetname almıştır. Sonraları Medrese-i Süleymaniye adını alan Medresetü'l-Mütehassısin'in Fıkıh ve Usül-i Fıkıh Şubesinde de üç sene tahsil yapmış ve buradan da pekiyi derece ile mezun olmuştur. Doktora için yazdığı Dört İmamın Nokta-i Nazarına Göre Ahkâm-ı Ridâ adlı tezi de Müderrisler Meclisince birinciliğe layık görülmüsstür. ${ }^{5} \mathrm{Bu}$ eğitimi esnasında Fatih dersiamla-

3 Sicak, Ahmet Sait, Kur'an Tefsirinde Öznellik, Ankara Okulu, Ankara, 2017, s. 14, 86.

4 Uçar, Hasan Hüseyin - Uçar, Ahmet Ali, Antalya İli Akseki İlçesi Sadıklar Köyü, Yayına Hazırlayan: Mustafa Nuri Özyılmaz, İzmir, 1990, s. 283.

5 “Riyazu'-Sâlihîn Mütercimi Sabık Diyanet İşleri Başkanı Hasan Hüsnü Erdem”, Diyanet İşleri Başkanlığ Dergisi, Cilt: XIII, Sayı: 6, Kasım-Aralık, 1974, s. 379-380; Ertan, Veli, "Erdem, Hasan Hüsnü”, Diyanet İslam Ansiklopedisi, X, 283.

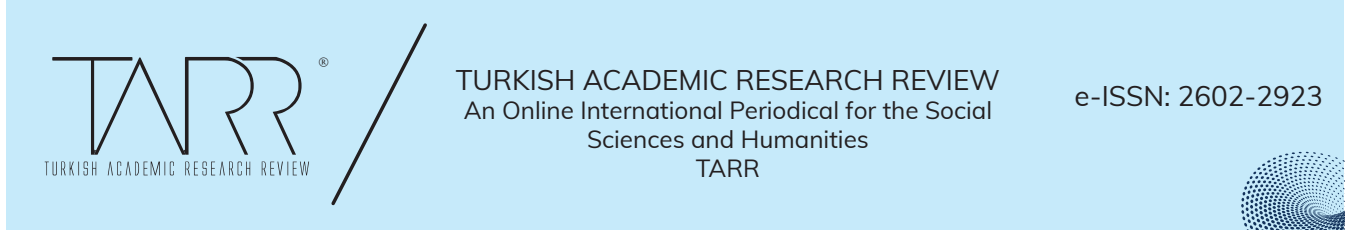


rından Burdurlu Şeyh Mustafa Efendiden tasavvuf ve özellikle de Mesnevi dersleri ald ${ }^{6}$

Hasan Hüsnü Erdem 1920 tarihinden itibaren Antalya Darü'l-Muallimin ve Mekteb-i Sultani'de Din Dersleri öğretmenliği yapmıştır. Bu esnada cuma günleri de Mehmet Paşa camisinde Milli Mücadele ile ilgili verdiği vaaz ve hutbelerle halk1 dinî yönden aydınlatmıştır. Vaaz ve hutbelerinden bazıları Antalya'da Tenvir ve Yeni Hayat gazetelerinde yayımlanmıștır. ${ }^{7}$ Ayrıca 1922 yılının Ramazan Bayramında Ankara Hacı Bayram Veli Camii’nde bir vaaz vermiştir. Bu vaazı Atatürk ve bakanlar dâhil olmak üzere zamanın üst düzey devlet erkânı ve geniş bir halk kesimi dinlemiştir. Namaz çıkışı yapılan bayramlaşma esnasında Atatürk, vaazdan duyduğu memnuniyeti kendisine bildirmiş ve o'nu tebrik etmiştir. ${ }^{8}$ Bu vaaz, Hâkimiyet-i Milliye ve Ögüt gibi Ankara gazetelerinde hakkında övgü dolu yazıların yayımlanmasına vesile olmuştur. ${ }^{9}$

Cuma günleri Antalya Paşa camisinde okumuş olduğu Arapça hutbeleri bir risale halindedir. Zamanın Milli Eğitim Bakanı Hamdullah Suphi Tanrı̈ver de bir hutbesine şahit olmuş ve bir sonraki Cuma bu hutbenin Türkçe olarak okunmasını rica etmiştir. Tanrı̈over Ankara'ya döndüğünde izlenimlerini o zamanın Şer'iye ve Evkaf Vekili Mustafa Fehmi Efendi'ye anlatmış ve bunun üzerine vekil de İslam'ın yüksek hakikatleri çerçevesinde halkı irşat etmesi sebebiyle duyduğu memnuniyeti ve vaaz ve irşatlarını yakından takip ettiğini bildiren bir mektubu Hasan Hüsnü Erdem'e göndermiştir. ${ }^{10}$ Ankara'nın dikkatini çeken Erdem'in çabaları kısa bir zaman içinde ödüllendirilmiş ve Ankara Daru'l-Hilâfe Medresesi Fıkıh ve Mecelle gurubu müderrisliğine ve müdürlügüune; oradan da başarıları sebebiyle Umûr-i Şer'iyye ve Evkaf Vekâleti Tedrisat Heyeti Azalığına tayin edilmiştir. Bu vekâletin ilgası üzerine de Antalya İmam-Hatip okulunun orta bölümünde tevhit, tefsir, hadis ve pedagoji derslerine asaleten; pedagoji kısmında da psikoloji, sosyoloji ve pedagoji derslerine vekâleten atanmıştır. Daha sonra din derslerinin ilgası üzerine Antalya Orta Okulu ve Lisesiyle Isparta Orta Okulunda Türkçe öğretmenliğine atanmıştır. Onun sade ama bir o kadar da etkili anlatım üslubunun oluşmasında verdiği bu derslerin büyük etkisi vardır. ${ }^{11}$

6 Uçar, Hasan Hüseyin - Uçar, Ahmet Ali, Sadıklar Köyü, s. 284.

7 "Hasan Hüsnü Erdem”, İslâm-Türk Ansiklopedisi Muhîtü'l-Maarif Mecmuası, Cilt: II, Sayı: 65-66, 1946, s. 6; Göküş, Şeref “Altıncı Diyanet İşleri Başkanı Hasan Hüsnü Erdem: Hayatı, Eserleri ve Başkanlığı Dönemindeki Yaygın Din Eğitimi Faaliyetleri”, TYB Akademi, Yıl: 9, Sayı: 25, Ocak 2019, s. 112-113.

8 Uçar, Hasan Hüseyin- Uçar, Ahmet Ali, Sadıklar Köyü, s. 287; Göküş, “Altıncı Diyanet İşleri Başkanı Hasan Hüsnü Erdem: Hayatı, Eserleri ve Başkanlığı Dönemindeki Yaygın Din Eğitimi Faaliyetleri”, s.113-114.

9 Ertan, “Erdem, Hasan Hüsnü”, X, 283.

10 Ertan, Veli, "Yaşayan Din Âlimlerinden Eski Diyanet İşleri Başkanı Üstad H. Hüsnü Erdem”, Bugün, 26 Şubat 1973, s. 4; Göküş, "Altıncı Diyanet İşleri Başkanı Hasan Hüsnü Erdem: Hayatı, Eserleri ve Başkanlığı Dönemindeki Yaygın Din Eğitimi Faaliyetleri”, s. 114.

11 Uçar, Hasan Hüseyin - Uçar, Ahmet Ali, Sadıklar Köyü, s. 297; Göküş, “Altıncı Diyanet İşleri Başkanı Hasan Hüsnü Erdem: Hayatı, Eserleri ve Başkanlığı Dönemindeki Yaygın Din Eğitimi Faaliyetleri”, s. 112.

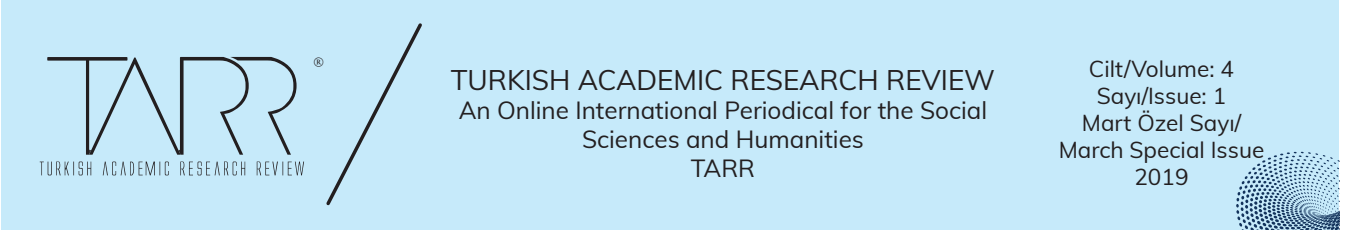


1944 yılında 4631 sayılı Kanunla Diyanet İşleri Başkanlığı Müşavere Heyeti Azalığına; daha sonra da ilmî yeterliliği sebebiyle zamanın Diyanet İşleri Başkanı Ahmet Hamdi Akseki tarafından bu heyetin başkanlığına getirilmiştir. ${ }^{12}{ }^{1952}$ 'de Ankara Üniversitesi İlahiyat Fakültesinde Tefsir ve Tefsir Tarihi öğretim görevlisi olmuş; 6 Mart 1961 tarihinde Ömer Nasuhi Bilmen'in emekliye sevk edilmesi üzerine 6 Nisan 1961 tarihinde Diyanet İşleri Başkanlığına getirilmiştir ve üç yıl altı ay ve yedi gün bu görevi yürütmüştür. ${ }^{13}$ Ömer Nasuhi Bilmen'den sonra başkan olan Hasan Hüsnü Erdem, 6 Nisan 1961'de başladığı Diyanet İşleri Başkanlığ1 görevini 13 Eylül 1964'te zorunlu olarak emekliliğe sevk edilmesi sonucu bırakmıştır. ${ }^{14} \mathrm{Bu}$ ani emeklilik halk üzerinde derin bir hüzün yaratmıştır. ${ }^{15} \mathrm{Bu}$ üzüntüyü o gün çıkan gazetelerden anlamak mümkündür. Emeklilikten sonra kendini mütevazı evinde ilim ve ibadete vermiştir. ${ }^{16}$

Başkan olduğunda yayınladığı genelgede din adamının takınması gereken şiarı şu cümlelerle ifade etmiştir: "Müftü, vaiz, dersiam ve imam-hatiplerimize karş1 vatandaşlarımızın hususi bir sevgi ve saygı taşıdıkları, onların da buna tamamen layık oldukları muhakkaktır. O halde meslektaşlarımızı mühim vazifeler beklemektedir. Gerek bu günlerden gerekse bundan sonra milli tesanüdümüzü sarsma$\mathrm{y} 1$ istihdaf eden her çeşit iç ve dış tesirlerin menfi telkinlerine asla kapılmamaları, millet ve fertleri arasında mevcut birlik ve kardeşlik duygusunu sarsacak hal ve hareketlerden son derece sakınmaları, gönül ve el birliğiyle çalışmaları hususunda vatandaşlarımızı her fırsatta ve vesileyle aydınlatmaları bu vazifelerin başında gelmektedir." ${ }^{17}$

Arap ve Fars edebiyatına vakıf olan Hasan Hüsnü Erdem doğunun ilim ve hikmetinden haberdar olduğu kadar batının kültürünü de iyi tanıyan; Kur'an, sünnet, ilim ve irfan geleneğine sahip çıkan bir âlimdi. ${ }^{18}$ Tercüme ve telif ettiği eserleri onun, ilmî çizgisinin göstergesidir. Onun Riyâzü̈s-Sâlihîn ve Tercemesi, ${ }^{19}$ Kırk Kutsi Hadis $^{20}$ ve İlahi Hadisler ${ }^{21}$ isimli eserleri sünnet konusundaki duyarlılığının bir ifadesidir. Ayrıca o, Riyâzü's-Sâlihîn hadislerinin ravileri olan sahabeden ve hadis imamlarından üç yüz kişinin hayatını incelediği bir eser kaleme almış ve

12 Uçar, Hasan Hüseyin - Uçar, Ahmet Ali, Sadıklar Köyü, s. 287.

13 “Riyazu'-Sâlihîn Mütercimi Sabık Diyanet İşleri Başkanı Hasan Hüsnü Erdem”, s. 380-381. Bkz. “Ö. N. Bilmen Sıhhî Sebeplerden Dolayı Emekli Oldu-Diyanet İşleri Reisliğine H. Hüsnü Erdem Tayin Edildi”, Yeni İstiklal, 12 Nisan 1961; Göküş, “Altıncı Diyanet İşleri Başkanı Hasan Hüsnü Erdem: Hayatı, Eserleri ve Başkanlığı Dönemindeki Yaygın Din Eğitimi Faaliyetleri”, s. 118.

14 "Diyanet İşleri Başkanı Ö. Bilmen Emekliye Ayrıldı Yerine Hasan Hüsnü Erdem Tâyin Edildi”, Tercüman, 6 Nisan 1961.

15 “İstenilen Fetvaları Vermeyen Diyanet İşleri Başkanı Emekliye Sevkedildi: Karar Büyük Üzüntü Yaratt1”, Zafer, 13 Ekim 1964.

16 Uçar, Hasan Hüseyin - Uçar, Ahmet Ali, Sadıklar Köyü, s. 294.

17 Uçar, Hasan Hüseyin- Uçar, Ahmet Ali, Sadıklar Köyü, s. 290.

18 Ertan, "Yaşayan Din Alimlerinden Eski Diyanet İşleri Başkanı Üstad H. Hüsnü Erdem”, s. 4.

19 Bu tercüme hakkında bir çalışma için bkz.: Atay, Rıfat, "Hasan Hüsnü Erdem'de Yorum: Riyazu's-Salihin Tercümesi Örneği," Altıncı DİB. Hasan Hüsnü Erdem Sempozyumu Bildirileri, Ed., Mehmet Şahin, Ankara, TDV Yay., 2019.

20 Ali el-Kârî'nin el-Ehâdîsü'l-Kudsiyye'sinin tercümesidir.

21 Müellif bu çalışmasında çeşitli eserlerden istifade etmekle birlikte ana hatlarıyla Abdurraûf Münâvî’nin el-îthâfü's-Seniyye'sini esas almıştır.

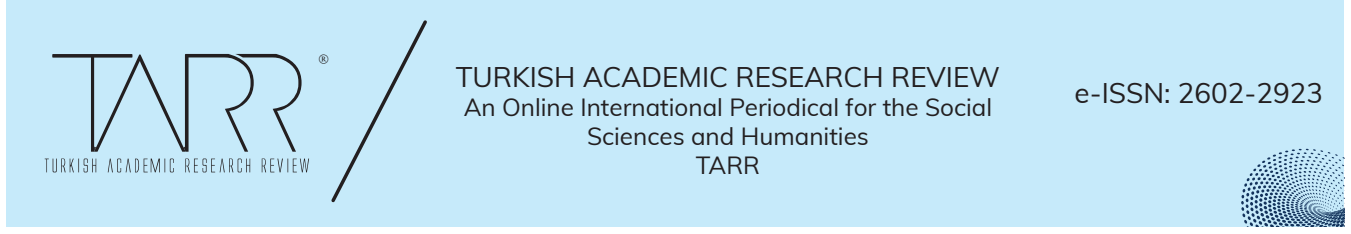


eser Diyanet İşleri Başkanlığı tarafından basılmıştır. Bunun yanı sıra İslam-Türk Ansiklopedisinin “A-B-D” maddeleri arasında yayınlanan 250 İslam Büyüğünün Hal Tercemesi de onun ilim ve irfan geleneğiyle arasındaki güçlü bağı ifade etmesi bakımından önemlidir. ${ }^{22}$

$\mathrm{O}$, dinde içtihat konusunda kendisine yöneltilen bir soruyu cevaplandırırken özetle şunları söylemektedir: "Zaman içinde, Kur'an ve sünnette açıkça hükmü bulunmadığ 1 için içtihada konu olan bir takım fer'i meseleler ortaya çıkabilir. Bu meseleler ancak Kur'an'ı, sünneti ve mezhep imamlarının görüşlerine tam anlamıla vakıf olan ilim ehli kimselerce çözüme kavuşturulabilir. Zamana göre değişen dinî hükümler de bu fer'i meselelere ilişkin hükümler için söz konusu olur. Nas ile sabit olan konularda bir reform söz konusu olamaz." ${ }^{23}$

10 Mayıs 1963 tarihinde Ankara Kocatepe site alanında yapılan temel atma töreninde ${ }^{24}$ bir konuşma yapmış ve genelde aydın kesimin oturduğu Yenişehir Semti'nde cami bulunmadığı için bir girişimde bulunduklarını ve "Yenişehir'de Bir Cami Yaptırma Derneği” adı altında bir cemiyet kurduklarını belirmiștir. Ancak, 27 Mayıstan sonra derneğin adının "Türkiye Devrim Diyanet Sitesi Yaptırma Derneği” olarak değiștirildiğini ifade ettikten sonra şunları söyler: "Burada bilhassa şu noktayı açıklamak isterim ki, "Diyanet Devrim Sitesi” tabirinin taşıdığ mana, dinimizin inanış, ibadet ve ahlak temelleri üzerinde asla herhangi bir değişiklik ifade etmez. 27 Mayıstan sonra modern Türk mimarisinin şaheser bir örneği olarak muazzam, mükemmel bir külliye inşası azmini ifade eder." ${ }^{25}$

22 Hasan Hüsnü Erdem'in basılmamış eserleri de onun ilim ve irfan geleneğinden beslenen bir âlim olduğunu göstermektedir. Onun basılmamış eserleri şunlardır: "Dört Mezhebe Göre Süt-Annelik ve Süt Kardeşliğin Hükümleri, el-Edebü'n-Nebevî Tercemesi (Eserin tam adı, el-Edebü'n-Nebevî Muhtârât min Ehâdîsi'r-Rasûl fî Edebi'd-Dünyâ ve'd-Din'dir. Muhammed Abdülaziz Havlî tarafından telif edilmiștir.) Duânın Âdâb ve Șerâiti, Müslümanlıkta İlmin Değeri, Kur'an-ı Kerim'in Fezâili, Peygamberimiz'in Okuma-Yazma Bilip Bilmediği Hakkında Bir Tetkik, Abdullah İbn-i Ömer'in Rivayet ettiği Hadislerden Seçmeler, Antalya Paşa Cami-i Şerifinde Irad Etmiş Olduğu Hutbeler."

Onun basılmış eserleri de şunlardır: Riyazü's-Sâlihîn ve Tercemesi, Riyâzü's-Sâlihîn Hadislerinin Ravileri Olan Ashâb-ı Kirâm'ın, Hadis İmamlarının Hal Tercemeleri, Kırk Kudsî Hadis (Terceme eser olup Başkanlık yayınları arasında iki defa bastırılmıştır.) İlâhi Hadisler (Terceme olup Başkanlık yayınları arasında iki defa bastırılmıştır.) Oruç ve Ramazan Íbadetlerine Dair 101 Hadis (Terceme olup Başkanlık'ça dört defa bastırılmıştır.) Berat Gecesi Hakkında Bir Tetkik (Başkanlıkça bastırılmıştır.) Ağaç Sevgisinin Önemi Hakkında Ayet ve Hadis Mealleri (Başkanlık yayınları arasında (Ağaç Sevgisi)) adlı eserde yayınlanmıştır.) Abdest Almanın Diş ve Göz Sağ̆lğı Bakımından Önemi (Başkanlık yayınları arasında bastırılmıştır.) Ebedi Risalet (Mısırlı Abdurrahman Azzam Pasa'nın yazdıgı er-Risâletü’l-Hâlide adlı Arapça eserin tercümesi olup Başkanlık yayınları arasında bastırılmış ve mevcudu kalmamıştır. İkinci baskısı Sönmez Neşriyat tarafından yapılmıştır.) 250 İslam Büyü̆günün Hal Tercemesi (İslam- Türk Ansiklopedisinin “a-b-d” maddeleri arasında yayınlanmıştır.) Bkz. "Riyazu'-Sâlihîn Mütercimi Sabık Diyanet İşleri Başkanı Hasan Hüsnü Erdem”, s. 383-384. Ayrıca bkz. “Diyanet Reisliğinde Tebeddül”, Sebilurreşad, Cilt: 13, Sayı: 320, İstanbul, 1961, s. 318-319. Göküș, "Altıncı Diyanet İșleri Başkanı Hasan Hüsnü Erdem: Hayatı, Eserleri ve Başkanlığı Dönemindeki Yaygın Din Eğitimi Faaliyetleri”, s. 117-118.

23 Erdem, Hasan Hüsnü, "Dinde İçtihad - İslam Dininde Reform - Türkçe Kur'an - Diyanet Teşkilatı Hakkında", (Diyanet Reisinin Mühim Beyanat1), Sebilurreşad, Cilt: 13, Sayı: 322, İstanbul, 1961, s. 354.

24 Tayla, Hüsrev, “Kocatepe Camii”, Diyanet İslam Ansiklopedisi, XXVI, 141; Göküş, "Altıncı Diyanet İşleri Başkanı Hasan Hüsnü Erdem: Hayatı, Eserleri ve Başkanlığı Dönemindeki Yaygın Din Eğitimi Faaliyetleri”, s. 130-131.

25 Hasan Hüseyin Uçar - Ahmet Ali Uçar, Sadıklar Köyü, s. 293.

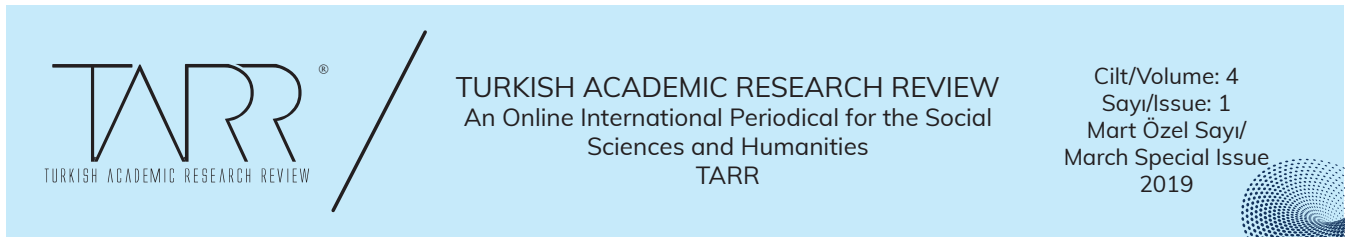


$\mathrm{O}$, hem halkın hem de öğrencilerinin ve arkadaşlarının nazarında âlim, ilmiyle amil, ahlaklı, dik duruşlu ve muhabbetli bir kişilikti. ${ }^{26}$ Öyle ki, emekliliğinin ardından 5-12 Ağustos 1965 tarihinde Ankara'da yapılan müftüler toplantısında Türkiye'nin bütün il ve ilçelerinden gelen 638 müftü, liyakat, cesaret ve başarıyla gerçekleştirdiği hizmetleri sebebiyle ona saygı ve bağlılıklarını sunmuş ve bunu bir telgraf ile taraflarına bildirmişlerdir. Bunun sebebi onun hem ilmiyle hem de ahlakıyla insanlara rehberlik etmiş olmasıdır. O, başkan olduğu dönemde makam aracına binme konusunda bazen makam şoförüne öncelik verecek kadar mütevazı ve nazik bir kişidir. Bütün gücünü, uhrevi kaygıların ve ulvi hedeflerin uğrunda harcamış, dünyaya tamah etmemiştir. Hatta kitaplarının basım hakkını sadaka-i cariye olsun diye Diyanet İşleri Başkanlığına vermiş ve bütün memuriyetinin karşılığ1 yalnızca Ankara'da satın aldığı bir ev olmuştur. ${ }^{27}$

Geniş bir ilmî ufka sahip olan Erdem, başkanlığı sırasında müftü, vaiz ve imam-hatiplerden ortaokul ve lise imtihanlarına girmelerini ve başbakanlıkça açılan kurslara katılmak suretiyle kendilerini müspet ilimlerde de geliştirmelerini istemiştir. $\mathrm{O}$, İslam Mecmuasına verdiği mülakatta, diyanet personeline akademik bir seviye kazandırmak istediğini bizzat ifade etmiştir. ${ }^{28}$ Ayrıca o, vaiz ve imamların mesleki yeterliliklerini geliştirmek için tekâmül kursları açmıştır. ${ }^{29}$

\section{Türkçe Kur'an ve Türkçe Ezan Meselesine Bakışı}

Hasan Hüsnü Erdem, aldığı Fıkıh ve Fıkıh Usulü eğitimi sayesinde dinin; zamanın değişmesiyle değişebilen ve değişmeyen ahkâmına ve bu değişimin ruh ve mantığa son derece vakıf bir âlimdi. İslam Mecmuası sahibi Kemalettin Şenocak'a 21 Nisan 1961'de verdiği mülakatta belli kesimlerden gelen reform talepleri karşısındaki mütalaalarını net bir şekilde ifade etmiş ve özetle şunlardan bahsetmiştir: "İslam en son ve en mükemmel din olup; onun temelleri üzerinde herhangi bir reform yapılması söz konusu olamaz. Ancak teferruat tarzındaki bazı konularda bir takım değissiklikler söz konusu olabilir. Örneğin, Türkçe Kur’an olmaz ve tercüme ile namazlarda kıraat yapılmaz. Kur'an'ın tercümesinin onun anlaşılmasına katkı sağlaması başka bir şeydir; bu tercümeyle teabbüd etmek başka bir şey." ${ }^{30}$

1961'de başkanlığı zamanında üç cilt olarak yayınlanan Kur'an'ı Kerim ve Türkçe Anlamı adını taşıyan meale yazdığı önsöz bir bakıma onun bir din âlimi olarak durduğu yeri ve Kur'an anlayışını göstermektedir. Erdem, eserin önsözünde

26 “Riyazu's-Sâlihîn Mütercimi Sabık Diyanet İşleri Başkanı Hasan Hüsnü Erdem”, s. 381. Ayrıca bkz. Hasan Özender, "Merhum Hasan Hüsnü Erdemi de Kaybettik”, İslam'ın İlk Emri Oku, Y.14, Cilt: 13, Ekim 1974, s. 15.

27 Uçar, Hasan Hüseyin - Uçar, Ahmet Ali, Sadıklar Köyü, s. 298. Bkz. Erdem, Dinde İçtihad - İslam Dininde Reform - Türkçe Kur'an - Diyanet Teşkilatı Hakkında”, (Diyanet Reisinin Mühim Beyanatı), s. 355; Göküş, “Altıncı Diyanet İşleri Başkanı Hasan Hüsnü Erdem: Hayatı, Eserleri ve Başkanlığı Dönemindeki Yaygın Din Eğitimi Faaliyetleri”, s. 115-116.

28 Uçar, Hasan Hüseyin - Uçar, Ahmet Ali, Sadıklar Köyü, s. 291.

29 Bkz. Erdem, Dinde İçtihad - İslam Dininde Reform - Türkçe Kur'an - Diyanet Teşkilatı Hakkında”, (Diyanet Reisinin Mühim Beyanat1), s. 355.

30 Uçar, Hasan Hüseyin - Uçar, Ahmet Ali, Sadıklar Köyü, s. 290-291. Bkz. Ertan, "Yaşayan Din Âlimlerinden Eski Diyanet İşleri Başkanı Üstad H. Hüsnü Erdem”, s. 4.

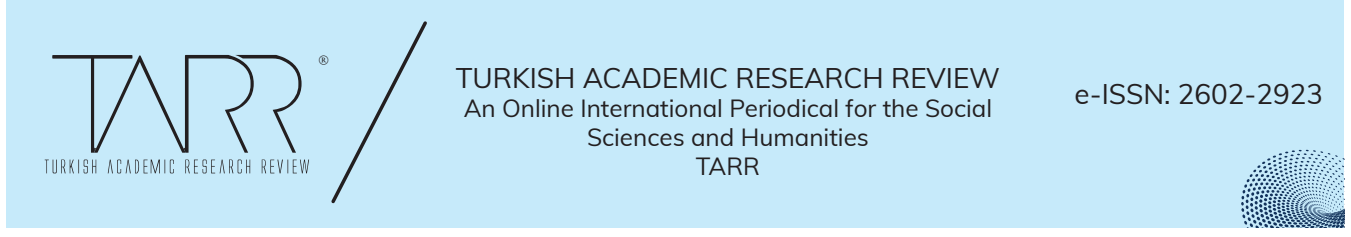


Kur'an'1-Kerim'i gerek vahyolunduğu dil ve 1stılahlar, gerekse taalluk ettiği geniş İslam kültürü bakımından en iyi anlayanların ilk müfessirler olduğunu belirtir. Mütekaddim dönem müfessirlerinin eserlerini ve bu husustaki bütün ciddi neşriyatı -son zamanlardakine varıncaya kadar- göz önünde tuttuğu için, bu mealin, benzerleri arasında belki hatası en az olmak vasfını taşıdığını ifade eder. ${ }^{31}$

Hasan Hüsnü Erdem'in başkanlık yaptığı dönem, Kur'an'ın Latin harfleriyle yazılıp yazılamayacağına ve Kur'an tercümelerinin Kur'an olarak isimlendirilip isimlendirilemeyeceğine ilişkin tartışmaların güçlü bir şekilde devam ettiği bir dönemdir. ${ }^{32}$ Bu bağlamda Erdem, bu önsöz içinde, Kur'an'ın ilahi belagat ve icaza sahip olduğu için Türkçeye veya herhangi bir dile tam olarak tercüme edilemeyeceğini, onun manasının ancak eski tefsirlerin ışığında aktarılabileceğini, bunun da tercüme değil, meal olarak isimlendirilebileceğini söyler. Çünkü her dilin kendine göre bir takım özellikleri vardır. Kur'an'ın bazı lafızlarının bazı dillerde uygun bir karşılığının bulunabileceğinden bahsetmek mümkündür. Ancak bunu Kur'an'ın tamamına şamil kılmak imkânsızdır. ${ }^{33}$ Kur’an, bazen bir kelimenin birden fazla manaya; bazen de birden fazla kelimenin bir tek manaya delalet ettiği "vücûh ve nezâir" (çok anlamlılık) boyutuna sahip bir kitaptır. Bu özelliklere sahip ilahi bir kitap olan Kur'an'ın lafızları tercüme edildiğinde o'nun kendine has delalet boyutu kaybolacağından lafızlar tercih edilen anlam çerçevesinde ister istemez tahsis edilmiş olacaktır. Bu sebeple hiçbir tercümenin aslın yerini tutamayacağını belirten Hasan Hüsnü Erdem'e göre tercümenin taşıdığı sorunlar, Kur'an'ın asla tercüme edilemeyeceğini ve anlaşılamaz bir kitap olduğunu da asla göstermez. $\mathrm{O}$, tercümenin, Kur'an'ın anlaşılmasına bir katkı sağlayacağını ama bu tercümeyi Kur'an hükmünde tutmanın, namazlarda okumanın ve ondan hüküm çıkarmanın caiz olmadığını belirtmektedir. ${ }^{34}$

Erdem'in, Kur'an'ın lafzen ve manen mucize oluşu ${ }^{35}$ sebebiyle herhangi bir dile hiçbir zaman tam olarak tercüme edilemeyeceğini ve taşıdığı eksiklikler sebebiyle tercümenin "meal” olarak isimlendirilmesi gerektiğini vurgulaması, Tanzimat Döneminden itibaren belirginlik kazanan ve Cumhuriyetin ilk yıllarından itibaren alevlenerek devam eden “Türkçe Kur'an ve Ana Dilde İbadet” çağrilarına bir itiraz niteliği taşımaktadır. O, elbette tercümenin, Kur'an'ın anlaşılmasına katkı sağlayacağını inkâr etmemekte; ama tercümeyi Kur'an hükmünde tutmanın, namazlarda okumanın caiz olmadığını vurgulamaktadır. Erdem'in, Kur'an diliyle ibadeti ümmetin birliği için en önemli vasıtalardan biri olarak gördügüunü ifade edebiliriz. O’nun Mekke'deki İslam'ın Sesi Radyosu'na yaptığı ve İslam kardeşliği-

31 Bkz. Hasan Hüsnü Erdem, “Kur’an’1 Kerim ve Meali”, Sebilürreşad, Cilt: XIV, Sayı: 329, s. 51. “Riyazu'-Sâlihîn Mütercimi Sabık Diyanet İşleri Başkanı Hasan Hüsnü Erdem”, s. 381-382.

32 Bkz. Aydar, Hidâyet, “Türklerde Kur'an Çalışmaları”, İstanbul Üniversitesi İlahiyat Fakültesi Dergisi, Sayı: 1, İstanbul, 1999, s. 208-212.

33 Bkz. Erdem, "Dinde İçtihad - İslam Dininde Reform - Türkçe Kur'an - Diyanet Teşkilatı Hakkında”, (Diyanet Reisinin Mühim Beyanat1), s. 355.

34 Erdem, “Kur'an'1 Kerim ve Meali”, s. 51-52; Riyazu'-Sâlihîn Mütercimi Sabık Diyanet İşleri Başkanı Hasan Hüsnü Erdem", s. 382.

35 Bkz. Erdoğan, İbrahim Halil, “Kur'ân'1 Mûcize Kılan İ'câz Yönü Fesâhat ve Tenâsüp Fahreddin erRâzî’ye Göre” Turkısh Academıc Research Revıew, Cilt:3, Sayı: 2, s. 39-60, 2018.

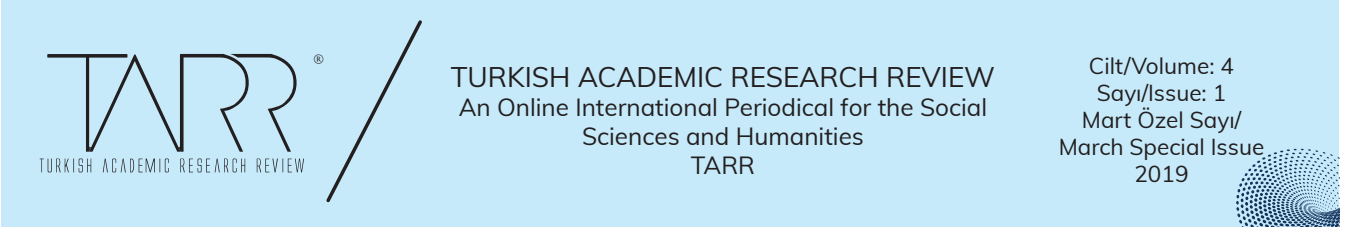


ni vurguladığı konuşması da ümmetin vahdeti konusundaki hassasiyetinin önemli bir göstergesi olarak kabul edilebilir. Erdem, bu konuşmasında özetle şunları söylemektedir: "Şunu da kat'i olarak ifade etmeliyim ki, Türk Milleti Allah'a ve Allah'ın Kitabına, Allah'ın Resulüne eskiden ne kadar bağlı idiyse bugün de o kadar bağlı bulunmaktadır. Camilerimizin daima cemaatle dolup taşması, en büyük şehirlerden en küçük köylere kadar yayılan Kur'an kurslarının her sene binlerce hafız yetiştirmekte olması, yer yer camiler inşasına devam edilmekte bulunması, her vesile ile mübarek gün ve gecelerde Peygamberimiz Efendimiz'e karşı sevgi, saygı ve bağlılık tezahürlerinde bulunulması bu bağlılığın canlı şahit ve delillerindendir." ${ }^{36}$

O'nun hassasiyet sahibi olduğu diğer bir konu da "Türkçe Ezan” meselesidir. Ankara Üniversitesi İlahiyat Fakültesi hocalarından Mehmet Sait Hatipoğlu diyor ki: "60 ihtilalinden sonraki Diyanet reislerimizden Hasan Hüsnü Erdem hocamız bizim fakültede dersler vermeye başlamıştı. Bir gün geldi, "Bugün ne oldu biliyor musunuz?" dedi. "Buyurun hocam ne oldu?" diye sordum. Gazeteciler Diyanet İşleri Başkanlığına yığılmışlar. İlk sordukları şey; "Ezan ne zaman Türkçe okunacak?"37 O da demiş ki: "Yarından tezi yok size bir cami tahsis edeceğim; orada Türkçe ezan da okunacak, namaz da Türkçe kılınacak. İçinizden kim gelecek? Parmak kaldırsın." Hiçbir parmak kalkmamış. Onun üzerine hocam da demiş ki: "Demek ki, bu iş lüzumsuz." ${ }^{8} \mathrm{O}$, ortaya koyduğu bu tavırla dinî hükümlerin değişebilir ve değişemez boyutlarına tam olarak vakıf olduğunu da ortaya koymuştur. $\mathrm{O}$, dinin özüne zarar vermeyen değişimin de öncülerindendir. Örneğin; Diyanet İşleri Başkanı Ahmet Hamdi Akseki'ye vekâleti esnasında, halkın talebi üzerine camilere mikrofon konulmasına cevaz vermiştir. ${ }^{39}$

\section{Enfâl Suresinin Altmışıncı Ayeti Hakkındaki Yorumu}

Milli Mücadele yıllarında hutbe ve vaazlarıyla Anadolu'nun uyanışı için büyük gayret sarf eden Hasan Hüsnü Erdem, Antalya Muallime ve Muallimler Cemiyeti’nin, 16 Kânunuevvel 1337 (16 Aralık 1921) Cuma günü Paşa Camisinde şehitler için okunan mevlitten önce bir vaaz verir. Vaazının ana teması Enfâl Suresi'nin 60. ayetidir. Allah bu ayette şöyle buyurmaktadır:

36 Hasan Hüsnü Erdem, “Mekke'de Faaliyete Geçen İslam’1 Sesi Radyosu'nun Talebi Üzerine Türkiye Cumhuriyeti Diyanet İşleri Başkanı Sayın Hasan Hüsnü Erdem Tarafından İslam Âlemine Hitaben Hazırlanan Arapça Konuşmanın Türkçe Tercümesi”, Diyanet İ̧̧leri Başkanlı̆̆ı Dergisi, Cilt: 1, Sayı: 1, Haziran, 1962, s. 27.

37 Her ihtilalden sonra gündeme getirilen Türkçe ezan uygulamasının maşeri vicdandaki etkisi üzerine geniş iki çalışma için bkz.: Atay, Rıfat, "Türkçe Ezan Uygulamasının Toplumsal Hafızada Yol Açtığı Travmalar Üzerine” Mukaddime, 9/2, 2018, ss. 49-66., Doi: 10.19059/mukaddime; Atay, Rıfat, "Türkçe Ezan Uygulamasının Toplumsal Hafızada Yol Açtı̆̆ı Travmalar," Ortak Dilimiz Ezan, Ed., Mahmut Öztürk, İstanbul, Nida Yayınc1lık, 2018, ss. 107-147.

38 Mehmet Said Hatiboğlu, “İslam'ın Doğru Anlaşılmasında ve Yaşanmasında Sünnetin Yeri” Sünnetin Bireysel ve Toplumsal Değişimdeki Rolü Sempozyumu Bildiriler Kitabı, Konya, 2008, s. 31.

39 Hasan Hüseyin Uçar - Ahmet Ali Uçar, Sadıklar Köyü, s. 289.

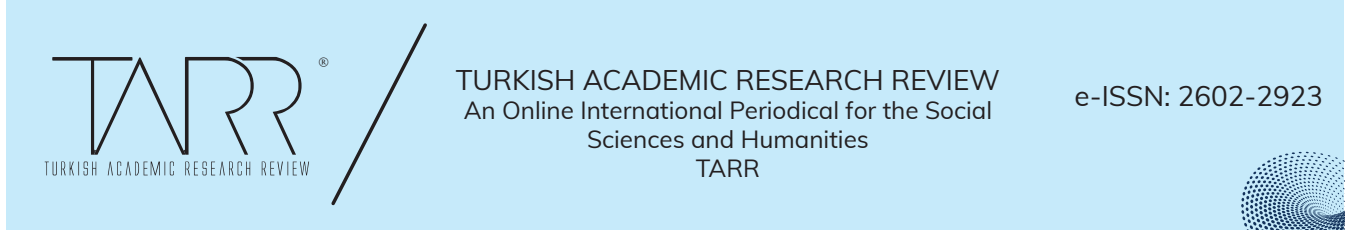




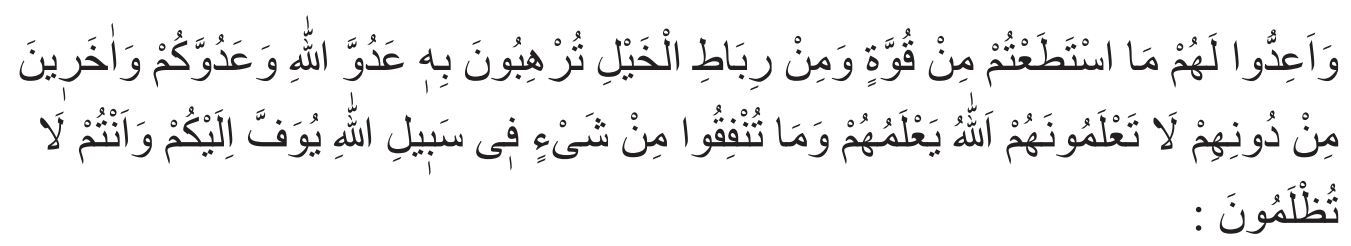

“Onlara karşı gücünüz yettiği kadar kuvvet ve savaş atları hazırlayın. Onlarla Allah'ın düşmanını, sizin düşmanınızı ve bunlardan başka sizin bilmediğiniz fakat Allah'ın bildiği diğer düşmanları korkutursunuz. Allah yolunda her ne harcarsanız karşıllğ̆ size tam olarak ödenir. Size zulmedilmez." 40

Bu vaaz, onun ilmî yetkinliğinin ve Kur'an'ın yorumlanmasında toplum psikolojisini ve buna ilişkin ihtiyaçları dikkate almasının somut örneklerinden biridir. Erdem, bu konuşmasında Müslümanların vatanlarına ve mukaddesatlarına tasallut etmek isteyen düşmanlara karşı hazırlık yapmanın ve her an tetikte olmanın bütün Müslümanlar üzerine bir borç olduğunu söyler. İslam'ın, maddi ve manevi hiçbir yönü ihmal etmeyen "zülcenâheyn” bir din olduğu gerçeğinden hareket eden Erdem, ayette geçen "وَاَعِدّو " : "hazırlayın" emrini hem maddi hem de manevi hazırlık olarak yorumlar. Başka bir deyişle düşmana karşı hazırlanmak maddi ve manevi olmak üzere iki cephede gerçekleşir. Çünkü o'na göre maddiyat bir beden, maneviyat ise o bedenin ruhu konumundadır; ruh olmadan benden nasıl işlevsiz ve anlamsız kalırsa manevi hazırlıkla desteklenmemiş maddi silah gücünün anlamı yoktur. Her iki unsurun da aynı anda inşası sağlanmadığı takdirde özelde bireyler, genelde de toplumlar için hezimet ve yok oluş kaçınılmazdır. O'na göre manevi hazırlığın iki temel unsuru din ve ahlaktır. ${ }^{41}$

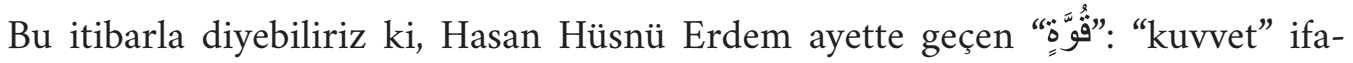
desini yalnızca maddi değil aynı zamanda hem aklî/ilmî hem de kalbî/irfânî güç anlamında manevi kudret şeklinde de yorumlamıştır. "Düşmana karşı güç hazırla-

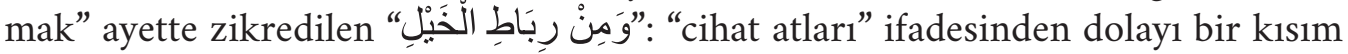
müfessirlerce, fiilî savaş durumu için gerekli olan savaş aletlerinin her çeşidine ${ }^{42}$ şamil olacak şekilde maddi bir hazırlık olarak anlaşılmıştır. ${ }^{43}$ Sahabeden Ebû Hammâd Ukbe İbni Âmir el-Cühenî (r.a.) Resûlullah (sav)'i minberde “Düşmanlarını için elinizden geldiği, gücünüzün yettiği kadar kuvvet hazırlayını. Dikkat ediniz! Kuvvet atmaktır; kuvvet atmaktır; kuvvet atmaktır." buyururken işittiğini haber vermektedir. ${ }^{44} \mathrm{~Hz}$. Peygamber'in, ilgili ayette geçen "kuvvet" kelimesini "atmak" şeklindeki tefsiri aslında her türlü askerî eğitim ve tatbikatı içermektedir. Çünkü bütün bunlar savaşa çıkmadan önce lüzumlu olan ve zafere ulaşmanın temelini

40 Enfâl, 8/60.

41 “Diyanet İşleri Başkanı Hasan Hüsnü Erdem'in Hal Tercemesi”, Diyanet İşleri Başkanlı̆̆ı Dergisi, Türk Tarih Kurumu Basimevi, Ankara, 1962, s. 260.

42 Râzî, Fahruddîn, Mefâtîhu 'l-Ğayb, Dâru İhyâi't-Turâsi'l-Arabiyy, Beyrût, 1420, XV, 499; Tantâvî, Muhammed Seyyid, et-Tefsîru'l-Vasît li'l-Kur'âni'l-Kerîm, Dâru'n-Nahda, Kâhire, 1998, VI, 142.

43 Taberî, Muhammed b. Cerîr, Câmiu'l Beyân fì Te 'vîli 'l-Kur'ân, Thk. Ahmed Muhammed Şâkir, Müssesetü'r-Risâle, 1420/2000, XIV, 31; Râzî, İbn Ebî Hâtim, Tefsîru'l-Kur'âni'l-Azîm, Thk. Es'ad Muhammed Tayyib, Mektebetü Nizâr Mustafa el-Bâz, Suûd, 1419, V, 1722; Sa'lebî, Ahmed b. Muhammed, el-Keşfü ve'l-Beyân an Tefsîri'l-Kurân, Thk. Ebû Muhammed b. Âşûr, Dâru İhyâi't-Turâsi'l-Arabî, Beyrût, 1422/2002, IV, 369; Mekkî b. Ebî Tâlib, el-Hidâye ilâ Bülûğu'n-Nihâye, Thk. Mecmûatü Resâil Câmiiyye bi Külliyyâti'd-Dirâsâti'l-Ulyâ ve'l-Bahsi'l-İlmî Câmiatu'ş-Şârika, Mecmûatu Buhûsi'l-Kitâbi ve's-Sünne, y.y., 1429/2008, IV, 2862.

44 Müslim, "İmâre”, 167; Ebû Dâvûd, "Cihâd”, 23; Tirmizî, "Tefsîru’s-Sûre”, 5; İ̉n Mâce, "Cihâd”, 19.

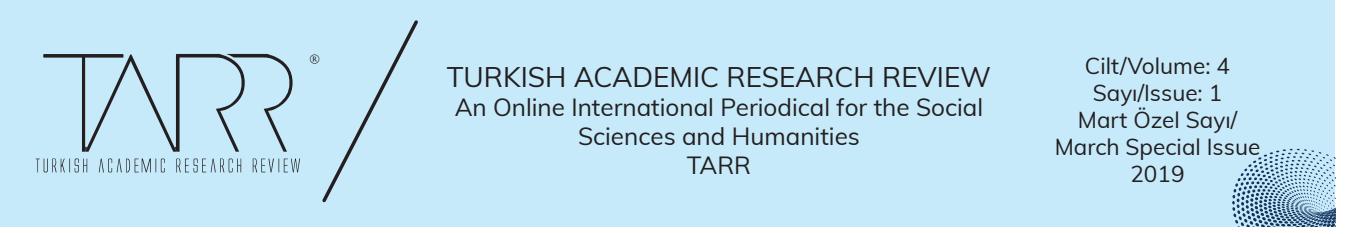


teşkil eden unsurlar olup bunlarda eksikliği olan bir ordunun savaşta galip gelmesi düşünülemez. Bu sebeple Allah Resulü başka bir hadisinde "Her kim atıcıllğ öğrenir de sonra terk ederse bizden değildir. Yahut muhakkak isyan etmiștir." ${ }^{45}$ buyurmuş ve atıcılığı öğrendikten sonra unutacak düzeyde terk etmeyi bir küfrân-1 nimet olarak kabul etmiştir. ${ }^{46}$ Söz konusu hadis-i şerifler ayette geçen "kuvvet"in maddi boyutuyla ilgili bir ihmalkârlığın mazur görülemeyeceğine delil teşkil etmektedir. Bununla birlikte diğer bir grup müfessir bu "kuvvet"i maddi gücün yanı sıra Allah'a güvenmek ve yönelmek, ${ }^{47}$ maddi savaş unsurlarını tamamlayan ak1l, ${ }^{48}$ kalp, ${ }^{49}$ niyet ve basiret gücü ${ }^{50}$ ve infak ${ }^{51}$ gibi manevi unsurlarla tefsir etmişlerdir. Bu itibarla savaş için gerekli olan "kuvvet"in silah ile sınırlı olmadığı anlaşılmaktadır. ${ }^{52}$

Hasan Hüsnü Erdem'in mefkûresinde maddi kuvvet Allah yolunda cihadın, inkâr ve ihmal edilmesi asla düşünülemeyecek temel unsurlarından biridir. Ancak o'na göre düşmana hazırlık yapmak konusunda her ne kadar öncelikle maddi imkânlar akla gelse de, asıl olan manevi hazırlıktır. Yüksek hakikatlere iman sayesinde elde edilmiş manevi kudret olmaksızın temin edilen maddi imkânlar ne denli kusursuz olursa olsun kalıcı zaferi getirmekten acizdir. $\mathrm{O}$, ahlakı ve maneviyatı bozulmamış bir milletin mağlup, hatta esir bile olsa eninde sonunda esaret zincirini kırıp galip geleceğini söyler. Erdem; kadın erkek, genç yaşlı her bir ferdiyle bütün İslam âlemine düşen görevin; vatanı ve dini korumak için ellerinden geleni yapmak ve mukaddesata saldıran düşmana karşı olanca güçleriyle direnmek olduğunu belirtir. Çünkü o'na göre vatan, dinin yaşam alanıdır. Vatanın ortadan kalkması dinin de ortadan kalkması anlamına gelir. ${ }^{53}$ Vatanını kaybeden Endülüs Müslümanları dinlerini de kaybetmişlerdir. Vatana saldırı dine saldırıdır. Ona saldıranların hedefi de aslında dini ortadan kaldırmaktır. Bundan dolayı zenginin, servetiyle; âlimin, ilmiyle; gücü kuvveti yerinde olanların da silahla bu vatanı korumaları ve mukaddesata uzanan elleri kırmaları dinin bir emridir. Şu halde milletin varlık ve bekas1nı sağlayacak en büyük güç; ilim ve irfandır. ${ }^{54}$ Bu bağlamda Erdem, Kur’an’ın Hz.

45 Müslim, "İmâre", 169.

46 Ebû Dâvûd, "Cihâd”, 23; Tirmizî, "Fezâilü’l-Cihâd”, 11; Nesâ̂,, "Hayl”, 8.

47 Mâverdî, Ebû'l-Hasen Ali b. Muhammed, en-Nüket ve'l-Uyûn, Thk. es-Seyyid İbn Abdulmaksûd b. Abdirrahîm, Dâru'l-Kütübi'l-İlmiyye, Beyrût, ts., II, 329;

48 Sa'dî, Abdurrahmân b. Nâsır b. Abdullah, Tefsîru'l-Kerîmi'r-Rahmân fí Tefsîri Kelâmi 'l-Mennân, Thk. Abdurrahmân b. Muallâ, Müessetü'r-Risâle, 1420/2000, s. 324.

49 Tüsterî, Ebû Muhammed, Tefsîru Tüsterî, Thk. Muhammed Bâsil Uyûnu's-Sûd, Dâru'l-Kütübi'l-İlmiyye, Beyrût, 1423, s. 635.

50 Herrâsî, İlkiyâ İmâduddîn, Ahkâmu'l-Kur'ân, Thk. Musâ Muhammed Ali - İzzet Abdu Atıyye, Dâru'l-Kütübi'l-İlmiyye, Beyrût, 1405, III, 164.

51 İbn Âşûr, Muhammed Tâhir, Tahrîru'l-Ma'ne 's-Sedîdve Tenvîru'l-Akli'l-Cedîd min Tefsîri'l-Kitâbi'l-Mecîd, ed-Dâru't-Tûnûsiyye, Tûnus, 1984, X, 57. Şa'râvî, Muhammed Mütevellî, Tefsiru'ş-Şa'râvî: elHavâtır, Matâbiu Ahbâri'l-Yevm, 1997, y.y., VIII, 4780.

52 Şa'râvî, Tefsiru'ş-Şa'râvî: el-Havâtır, VIII, 4779.

53 Benzer bir hassasiyeti Hasan Basri Çantay ve Mehmet Akif Ersoy’un hayatında da görmek mümkündür. Detaylı bilgi için bkz. Gürsu, Orhan, "Hasan Basri Çantay: Bir Psikobiyografi Denemesi", Ekev Akademi Dergisi, 62.62 (2015): 251-268, s. 251-268.

$54 \mathrm{Bu}$ konunun Mesnevi bağlamında bir değerlendirmesi için bkz.: Atay, Rıfat, "Bilgi ve Eylem Arasında Mevlana'da Estetik Değerler Eğitimi: Mesnevi Merkezli Bir Okuma Denemesi," Eğitimde Gelecek Arayışları Dünden Bugüne Türkiye'de Beceri Ahlak ve Değerler Eğitimi, Ed., Arzu Güvenç Saygın, Murat Saygın, Atatürk Araştırma Merkezi Yayınları, Ankara, 2016, Cilt: II, ss. 1233-1247.

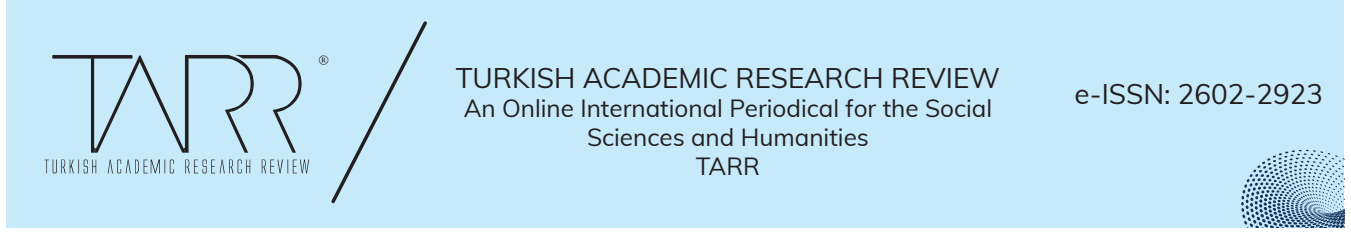


Peygamber'e ve elbette bütün müminlere yönelttiği ilk emrinin “Oku” olduğunu hatırlatır. Vatanın ve milletin bekası için ilmin önemini de vurgulayan Hasan Hüsnü Erdem, kadınların da ilim ve irfan sahibi olmalarının dinî bir vecibe olduğunu belirtir. Kadınlar da erkekler kadar ilim ve irfan sahibi olmaz iseler topyekûn bir terakki mümkün olmaz. Erdem, bu yorumunda neslin terbiyesinin kadının omuzlarında oluşu gerçeğinden hareket etmektedir. İyi eğitim almayan bir kadının, bu ağır görevi yerine getirmesi imkânsızdır. O'na göre her anne-babanın erkek ve kız ayrımı yapmaksızın çocuklarını okutması dinî bir sorumluluktur. ${ }^{55}$

\section{Sonuç}

Hasan Hüsnü Erdem; Kur’an, sünnet, ilim ve irfan geleneği ekseninde hareket eden muhakkik bir âlimdir. Erdem'in, Ömer Nasuhi Bilmen gibi büyük bir âlimden sonra Diyanet İşleri Başkanlığına getirilmiş olması, onun yerini doldurma konusundaki liyakatiyle yakından ilgilidir. İlim ve irfan Erdem'in şahsiyetinde aynı potanın içinde mayalanmıştır. Telif ve tercüme eserleri ve başkanlığı esnasındaki duruşu, onun İslam dininin temellerine olan sadakatinin, çağının sorunları karşısında dinî ve ilmî ölçülere riayetinin ve o dönemde sosyo-politik açıdan kendisine güçlü referanslar bulmuş modern ve post modern eğilimler karşısındaki istikametinin bir göstergesidir. O’nun, dinî ilimlerin yanında sosyoloji, psikoloji ve pedagojiye olan vukûfiyeti, redd-i miras yapmadan ve dinin temellerinden ayrılmadan kendi döneminin sorunlarına yaklaşmasına ve Kur'an ve sünnetinin ruhunun modern zamanda inşa edilmesine olanak sağlamıştır.

Erdem, kuru kuruya dinî ilimlerle uğraşıp zamanının sorunlarından gafil olan bir malumatfuruş değildir. Onun ilmî duruşunu, idrak gücünü ve düşünce ufkunu Diyanet İşleri Başkanı olarak gerçekleştirdiği icraatlarında, vaaz ve hutbelerinde görmek mümkündür. ${ }^{56} 16$ Kânunuevvel 1337 (16 Aralık 1921) Cuma günü Antalya Paşa Camisinde şehitler için okunan mevlitten önce yaptığı vaazda, Enfâl Suresinin 60. ayetinde zalimleri caydırmaları için Allah'ın müminlere emrettiği "kuvvet hazırlama"yi; öncelikle ve özellikle manevi eğitim ve ruhi terbiye ile ilişkilendirmesi dikkate şayandır. Onun, bireyi ve toplumu yüksek hakikat ve erdemlere taşıyacak manevi güce/mücadeleye, maddi güce/mücadeleye nispetle atfettiği konum akıllara "cihad-1 ekber" kavramını getirmektedir. Ayrıca o, söz konusu ayete getirdiği yorumda gerçek kurtuluşu ve kalıcı zaferi bütün boyutlarıyla dinin yaşanmasına, dinin yaşanmasını ve yaşamasını da vatanın bekasına bağlamıştır.

55 “Diyanet İşleri Başkanı Hasan Hüsnü Erdem'in Hal Tercemesi”, s. 261.

56 Örneğin; Ebedî Risâlet olarak Türkçeye tercüme ettiği Mısırlı Abdurrahman Azzam Paşa'nın yazdığı er-Risâletü'l-Hâlide eseri II. Dünya Savaşı sonrasında ortaya çıkan insanlık manzarasının ve evrensel ıstırabın sebeplerini araştırmak ve çare bulmak için kaleme alınmıştır. Erdem, Arap Birliği Genel Sekreteri Azzam Paşa'nın "İslam'da Mazluma Yardım İçin Harp” adlı bir makalesini de tercüme etmiştir. Ana hatlarıyla İslam'da savaşın; dünyevi ihtiraslar uğrunda değil, ancak mazlumlara yardım etmek ve bâtılın tecavüz ve tasallutlarını def edip hakkı galip kılmak için yapılması gerektiğinden bahseden bu makale Sebilurreşad dergisinin III. cildinin 54, 55, 57 ve 58. sayılarında yayınlanmıştır. Örneğin; bkz. Abdurrahman Azzam Paşa, "İslam'da Mazluma Yardım İçin Harp II", Tercüme: Hasan Hüsnü Erdem, Sebilürreşad, Cilt: 3, Say1: 54, s. 112.

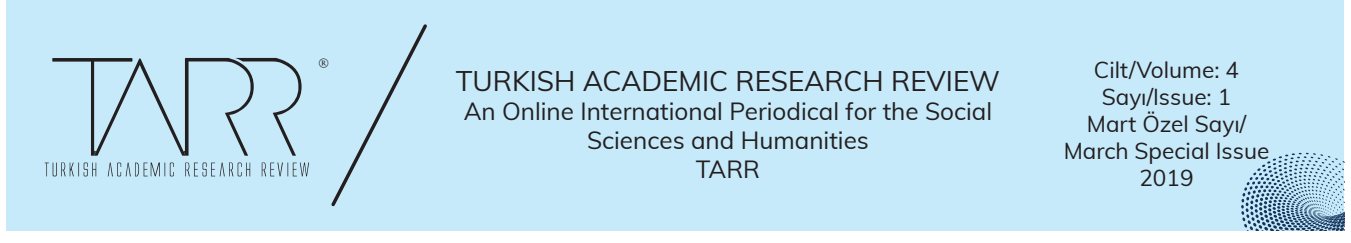




\section{Kaynakça}

“Diyanet İşleri Başkanı Hasan Hüsnü Erdem’in Hal Tercemesi”, Diyanet İșleri Başkanlığ Dergisi, Türk Tarih Kurumu Basımevi, Ankara, 1962.

“Diyanet Reisliğinde Tebeddül”, Sebilurreşad, Cilt: 13, Sayı: 320, İstanbul, 1961.

"İstenilen Fetvaları Vermeyen Diyanet İşleri Başkanı Emekliye Sevkedildi: Karar Büyük Üzüntü Yarattı", Zafer, 13 Ekim 1964.

“Riyazu'-Sâlihîn Mütercimi Sabık Diyanet İşleri Başkanı Hasan Hüsnü Erdem”, Diyanet İşleri Başkanlığı Dergisi, Cilt: XIII, Sayı: 6, Kasım-Aralık, 1974.

Abdurrahman Azzam Paşa, “İslam'da Mazluma Yardım İçin Harp II”, Tercüme: Hasan Hüsnü Erdem, Sebilürreşad, Cilt: 3, Sayı: 54.

Atay, Rıfat, "Bilgi ve Eylem Arasında Mevlana'da Estetik Değerler Eğitimi: Mesnevi Merkezli Bir Okuma Denemesi," Eğitimde Gelecek Arayışları Dünden Bugüne Türkiye'de Beceri Ahlak ve Değerler Eğitimi, Ed., Arzu Güvenç Saygın, Murat Saygın, Atatürk Araştırma Merkezi Yayınları, Ankara, 2016, Cilt: II.

, "Hasan Hüsnü Erdem'de Yorum: Riyazu's-Salihin Tercümesi Örneği," Altıncı DİB. Hasan Hüsnü Erdem Sempozyumu Bildirileri, Ed., Mehmet Şahin, Ankara, TDV Yay., 2019.

, "Türkçe Ezan Uygulamasının Toplumsal Hafızada Yol Açtığı Travmalar Üzerine” Mukaddime, 9/2, 2018, ss. 49-66., Doi: 10.19059/mukaddime.

“Türkçe Ezan Uygulamasının Toplumsal Hafızada Yol Açtığı Travmalar," Ortak Dilimiz Ezan, Ed., Mahmut Öztürk, İstanbul, Nida Yayınc1lık, 2018.

Aydar, Hidâyet, “Türklerde Kur'an Çalışmaları”, İstanbul Üniversitesi İlahiyat Fakültesi Dergisi, Sayı: 1, İstanbul, 1999.

Erdem, Hasan Hüsnü, “Dinde İçtihad - İslam Dininde Reform - Türkçe Kur'an - Diyanet Teşkilatı Hakkında”, (Diyanet Reisinin Mühim Beyanatı), Sebilurreşad, Cilt: 13, Sayı: 322, İstanbul, 1961.

“Mekke'de Faaliyete Geçen İslam'ı Sesi Radyosu'nun Talebi Üzerine Türkiye Cumhuriyeti Diyanet İşleri Başkanı Sayın Hasan Hüsnü Erdem Tarafından İslam Âlemine Hitaben Hazırlanan Arapça Konuşmanın Türkçe Tercümesi”, Diyanet İşleri Başkanlığı Dergisi, Cilt: 1, Sayı: 1, Haziran, 1962.

, “Kur’an’1 Kerim ve Meali”, Sebilürreşad, Cilt: XIV, Sayı: 329.

Ertan, Veli, “Erdem, Hasan Hüsnü”, Diyanet İslam Ansiklopedisi, X.

, "Yaşayan Din Âlimlerinden Eski Diyanet İşleri Başkanı Üstad H. Hüsnü Erdem”, Bugün, 26 Şubat 1973.

Erdoğan, İbrahim Halil, “Kur'ân'ı Mûcize Kılan İcâz Yönü Fesâhat ve Tenâsüp Fahreddin er-Râzîye Göre", Turkısh Academıc Research Revıew, Cilt:3, Sayı: 2.

Göküss, Şeref, "Altıncı Diyanet İşleri Başkanı Hasan Hüsnü Erdem: Hayatı, Eserleri ve Başkanlığı Dönemindeki Yaygın Din Eğitimi Faaliyetleri”, TYB Akademi, Yıl: 9, Sayı: 25, Ocak 2019.

Gürsu, Orhan, "Hasan Basri Çantay: Bir Psikobiyografi Denemesi”, Ekev Akademi Dergisi, $62.62(2015)$.

Herrâsî, İlkiyâ İmâduddîn, Ahkâmu'l-Kurân, Thk. Musâ Muhammed Ali - İzzet Abdu Atıyye, Dâru’l-Kütübi'l-İlmiyye, Beyrût, 1405.

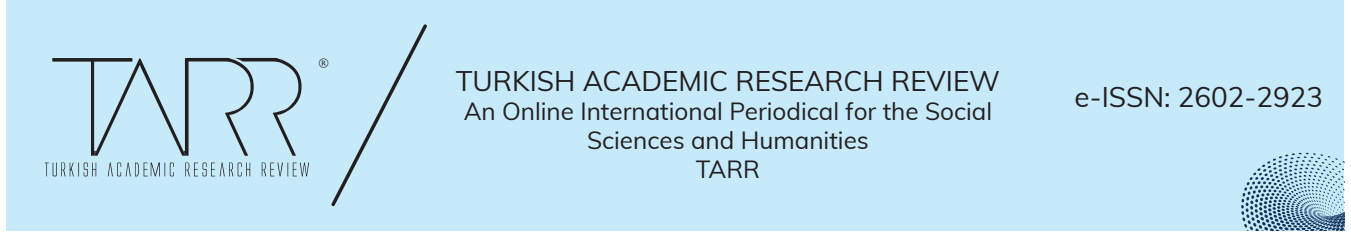


İbn Âşûr, Muhammed Tâhir, Tahrîru'l-Ma'ne's-Sedîd ve Tenvîru'l-Akli'l-Cedîd min Tefsîri'lKitâbi'l-Mecîd, ed-Dâru't-Tûnûsiyye, Tûnus, 1984.

Mâverdî, Ebû'l-Hasen Ali b. Muhammed, en-Nüket ve'l-Uyûn, Thk. es-Seyyid İbn Abdulmaksûd b. Abdirrahîm, Dâru'l-Kütübi'l-İlmiyye, Beyrût, ts.

Mehmet Said Hatiboğlu, "İslam'ın Doğru Anlaşılmasında ve Yaşanmasında Sünnetin Yeri”, Sünnetin Bireysel ve Toplumsal Değişimdeki Rolü Sempozyumu Bildiriler Kitabı, Konya, 2008.

Mekkî b. Ebî Tâlib, el-Hidâye ilâ Bülûğu'n-Nihâye, Thk. Mecmûatü Resâil Câmiiyye bi Külliyyâti'd-Dirâsâti'l-Ulyâ ve'l-Bahsi'l-İlmî Câmiatu'ş-Şârika, Mecmûatu Buhûsi'lKitâbi ve's-Sünne, y.y., 1429/2008.

Özender, Hasan, "Merhum Hasan Hüsnü Erdemi de Kaybettik”, İslam'in İlk Emri Oku, Y1l: 14, Cilt: 13, Ekim 1974.

Râzî, Fahruddîn, Mefâtîhu'l-Ğayb, Dâru İhyâi't-Turâsi'l-Arabiyy, Beyrût, 1420.

Râzî, İbn Ebî Hâtim, Tefsîru'l-Kur'âni'l-Azîm, Thk. Es'ad Muhammed Tayyib, Mektebetü Nizâr Mustafa el-Bâz, Suûd, 1419.

Sa'dî, Abdurrahmân b. Nâsır b. Abdullah, Tefsîru'l-Kerîmi'r-Rahmân fî Tefsîri Kelâmi'lMennân, Thk. Abdurrahmân b. Muallâ, Müessetü'r-Risâle, 1420/2000.

Sa'lebî, Ahmed b. Muhammed, el-Keşfü ve'l-Beyân an Tefsîri'l-Kurân, Thk. Ebû Muhammed b. Âşûr, Dâru İhyâi't-Turâsi'l-Arabî, Beyrût, 1422/2002.

Sicak, Ahmet Sait, Kur'an Tefsirinde Öznellik, Ankara Okulu, Ankara, 2017.

Şa'râvî, Muhammed Mütevellî, Tefsiru'ş-Şa'râvî: el-Havâttr, Matâbiu Ahbâri'l-Yevm, 1997, y.y.

Taberî, Muhammed b. Cerîr, Câmiu'l Beyân fî Te'vîli'l-Kur'ân, Thk. Ahmed Muhammed Şâkir, Müssesetü'r-Risâle, 1420/2000.

Tantâvî, Muhammed Seyyid, et-Tefsîru'l-Vasit li'l-Kur'âni'l-Kerîm, Dâru'n-Nahda, Kâhire, 1998.

Tayla, Hüsrev, “Kocatepe Camii”, Diyanet İslam Ansiklopedisi, XXVI.

Tüsterî, Ebû Muhammed, Tefsîru Tüsterî, Thk. Muhammed Bâsil Uyûnu's-Sûd, Dâru'lKütübi'l-İlmiyye, Beyrût, 1423.

Uçar, Hasan Hüseyin - Uçar, Ahmet Ali, Antalya İli Akseki İlçesi Sadıklar Köyü, Yayına Hazırlayan: Mustafa Nuri Özyılmaz, İzmir, 1990.

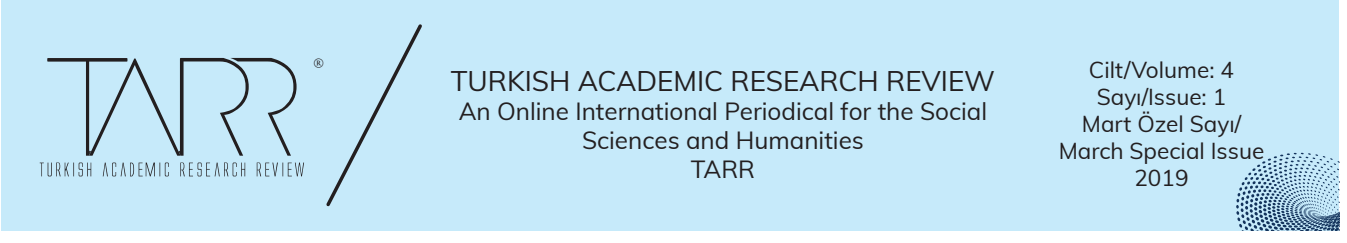


